\title{
Enhanced mesophilic bio-hydrogen production of raw rice straw and activated sewage sludge by co-digestion.
}

\author{
Nika Alemahdi ${ }^{\text {a* }}$, Hasfalina Che Man ${ }^{b}$, Nor'Aini Abd Rahman ${ }^{c}$, Nima Nasirian ${ }^{\mathrm{d}}$, Yignan Yang ${ }^{\mathrm{e}}$ \\ a Institute of Advanced Technology, Universiti Putra Malaysia, 43400 Serdang, Selangor, Malaysia \\ ${ }^{\mathrm{b}}$ Department of Biological and Agricultural Engineering, Faculty of Engineering, Universiti Putra Malaysia, \\ 43400 Serdang, Selangor, Malaysia \\ ${ }^{\mathrm{C}}$ Department of Bioprocess Technology, Faculty of Biotechnology and Biomolecular Sciences, Universiti Putra \\ Malaysia, 43400 Serdang, Selangor, Malaysia \\ ${ }^{\mathrm{d}}$ Department of Agricultural Mechanization, Shoushtar branch, Islamic Azad University, Shoushtar, Iran. \\ ${ }^{\mathrm{e}}$ Graduate School of Life and Environmental Sciences, University of Tsukuba, Tsukuba, Ibaraki 305-8577, Japan. \\ * Corresponding author: Tell: +6584347028, Fax: +60389466425, E-mail address: Nika.alemahdi@gmail.com
}

\begin{abstract}
:
In this study, batch biohydrogen production by co-digestion of raw rice straw and activated sewage sludge was investigated with different inoculum heat treatment, $\mathrm{pH}, \mathrm{S} / \mathrm{X}$ ratio (based on VS) and substrate sizes under mesophilic condition. In order to achieve a high bio-hydrogen yield and methanogens activity inhibition, heat treatment of inoculum was optimized at different exposure times $(30,45 \& 60 \mathrm{~min})$ and temperature ranges $(80$, 90 and $100{ }^{\circ} \mathrm{C}$ ) prior to dark fermentation process. Collected data was analysed using response surface methodology (RSM). The heat treatment of inoculum at $100{ }^{\circ} \mathrm{C}$ for 60 minutes produced the highest bio-hydrogen yield of $14.22 \mathrm{NmL} \mathrm{H}_{2} / \mathrm{g} \mathrm{VS}$ at concentration of $70.97 \%$ and Production of $0.073 \mathrm{NmLCH}_{4} / \mathrm{gVS}$ at $0.17 \%$ concentration in total produced biogas. The raw rice straw was also co-digested with heat-treated inoculum at different ratios of volatile solids $(2: 1,4: 1$ and $6: 1)$ and initial $\mathrm{pH}(4,4.75$ and 5.5) as numerical variables and 4 categories of substrate size $((250-500 \mu \mathrm{m}],(500 \mu \mathrm{m}-2 \mathrm{~mm}],(2-20 \mathrm{~mm}),[20-30 \mathrm{~mm}])$. The highest bio-hydrogen yield of $14.70 \mathrm{NmL} / \mathrm{g}$ VS was recognized at the optimum initial $\mathrm{pH}$ of 5.01 and S/X ratio of 4.54:1 using 2-20 $\mathrm{mm}$ rice straw.
\end{abstract}

Key words: Co-digestion, Activated sewage sludge, Rice straw, Response surface methodology, S/X ratio, Biohydrogen.

LIST OF ABBRIVIATIONS

ASS Activated Sewage Sludge S/X Substrata to inoculum ratio (based on VS)

HPY Bio-hydrogen Production Yield NmL Gas volume at NTP $\left(0{ }^{\circ} \mathrm{C}, 1013 \mathrm{hPa}\right)$

\section{Introduction}


Nowadays, many research works and pilot or industrial projects are being conducted all over the world revolving around biofuels. Bio-hydrogen as an energy career is becoming more attractive gradually and many studies cover wide range of issues in this field. Main subjects of these studies mostly include production, optimisation, method development and consumption of bio-hydrogen.

Bio-hydrogen inoculum and feedstock are the main components of bio-hydrogen production that can significantly affect bio-hydrogen production yield (HPY). Mixed culture is a mixture of different bacteria that contains a community of bio-hydrogen producer bacteria as well. Mixed culture can be obtained from aerobic or anaerobic sludge in wastewater treatment plants or compost piles or any other source of bacteria[1]. Since mixed culture contains different types of bacteria, it also contains methanogens or other hydrogen consuming bacteria. Methanogens, in one of their metabolism stages consume hydrogen to produce methane. Therefore, to produce bio-hydrogen from activated sewage sludge as a mixed culture, some treatment methods should be applied on it to inhibit methanogens activity or other hydrogen consuming bacteria [2]. There are few studies [3,4] that have used untreated mixed culture, but the yield is mostly lower compared to studies which have used treated mixed culture. There are many different methods to treat mixed microflora inoculum. Pretreatment methods reported in most research works mainly include heat-shock[2,5,6], acid[7,8], base [8], aeration, freezing and thawing, chloroform, sodium 2-bromoethanesulfonate or 2-bromoethanesulfonic acid [2], photocatalytic pretreatment [8,9] and ultrasonic treatments[8,10]. Heat shock is the most commonly used methods for treatment of mixed culture. Wide ranges of time, mostly from 15 to 80 minutes and temperature mostly from 60 to 120 ${ }^{\circ} \mathrm{C}$ have been reported in different studies to treat different types of mixed cultures [11-15].

Lignocellulosic waste materials are a huge group of biomasses that has bio-hydrogen production potential. Agricultural residues as a source of lignocellulosic waste materials are extensively used in bio-hydrogen production studies. Rice straw, wheat straw, sugar cane bagasse, beer lees, jackfruit peel and food waste are some of waste materials that are recently used in some research works for bio-hydrogen production [2,13,16-21] . Lignocellulosic materials have complex structure made from cellulose, hemicellulose, and lignin and consist of 50 to $80 \%$ carbohydrates in dry weight [22]. Pretreatment methods have been used to break down the complex structure of lignocellulose to make them a more bio-degradable feedstock for biofuel production. These methods can be divided to 3 major groups, Physical pretreatment (size reduction, stream explosion and gamma rays usage), Chemical pretreatment (acidic and alkaline pretreatments) and biological pretreatment (enzymatic pretreatment). Mostly, a combination of these technologies produces better results [23]. The overall goal of all these methods are to change the structural and compositional properties of lignocellulosic biomass like presence of lignin and hemicellulose, decrease crystallinity of cellulose and to enhance accessible surface area; moreover it is expected from these technologies to make cellulose and hemicellulose more accessible for enzymes and bacteria [22].It should be considered that these pretreatment methods are always costly and sometimes not environment-friendly due to the usage of acid, base or the amount of energy used. As an example, biological pretreatment that seems more environment-friendly compared to the chemical pretreatment, is recognized as a time consuming process (10 - 14 days) and cannot be considered as a proper industrial method. On the other hand, the requirements of this bio-process, large space for conducting the process and the controlled environment, make it less attractive for large and industrial scales [23]. Size reduction is one of the most simple and widely used physical treatment methods of lignocellulosic waste materials in both lab and industrial scales [23,24]. In most researches, very fine lignocellulosic particles are used as raw lignocellulose[4,25], while some researches indicate that size reduction less than $0.4 \mathrm{~mm}$ has not any significant effect on yield of lignocellulosic waste material hydrolyses $[4,23,26]$. Grinding and milling are used to make lignocellulosic particles smaller than $2 \mathrm{~mm}$. Since the Specific Energy Requirement (SER) to carry out milling or grinding is high, it is very important to do these mechanical treatments in a proper way [24].

Temperature is one the most affecting factors in bio-hydrogen production. Bio-hydrogen can be produced by mesophillic $\left(25\right.$ to $\left.40^{\circ} \mathrm{C}\right)$, thermophilic $\left(40\right.$ to $\left.65^{\circ} \mathrm{C}\right)$, extreme thermophilic $\left(65\right.$ to $\left.80^{\circ} \mathrm{C}\right)$ and hyperthermophilic $\left(>80^{\circ} \mathrm{C}\right)$ microorganisms of the archaea and bacteria domains[27]. Under the same operating conditions a thermophilic bioreactor has a higher yield of bio-hydrogen production compared to a mesophilic bioreactor. On the other hand, a thermophilic experiment consumes more energy compared to a mesophilic experiment, and the difference between yields in thermophilic and mesophilic is not always highly significant considering the 
difference in the amount of consumed energy. Conducting a fermentation process in the mesophillic condition by optimization of other effecting factors on HPY will save lots of energy which is important for a successful large scale project [28] .

$\mathrm{pH}$ is another important affecting factor for metabolism of microorganisms. The reason for that is $\mathrm{pH}$ directly affects hydrogenase activity or metabolic pathways [29]. Many studies are done to investigate pH effect on biohydrogen production using different inoculums and substrates [29-33]. Since most of the studies were conducted in batch mode without a $\mathrm{pH}$ controller, only the effect of initial cultivation $\mathrm{pH}$, shortly called initial $\mathrm{pH}$, on fermentative bio-hydrogen production was investigated. Many different $\mathrm{pH}$ rates are reported as the optimum $\mathrm{pH}$. Davila-Vazquez et al.,(2008),[34] reported pH 7.5 as the optimum pH, while Ramos et al.,(2012),[29] or Fan et al.,(2004), [35] have reported $\mathrm{pH} 5.5$ as the optimum initial $\mathrm{pH}$.

Volatile solid has a significant role in a successful fermentation process. S/X ratio (based on VS) could be an indicator of $\mathrm{C} / \mathrm{N}$ ratio. Effect of $\mathrm{C} / \mathrm{N}$ ratio is proven to be important for growth of microorganisms [36-38]. High initial VS impairs mass transfer between microorganisms and substrate while the very low VS restricts metabolisms in other ways. In different studies various ranges of initial total or volatile solids are elaborated $[29,39,40]$. There are few studies that deliberated S/X ratio for bio-hydrogen production [41].

This study tried to optimize bio-hydrogen production from co-digestion of RS and ASS in mesophilic conditions. To accomplish this objective, optimum conditions for heat treatment of used inoculum in this study were determined and subsequently optimum $\mathrm{pH}, \mathrm{S} / \mathrm{X}$ ratio (based on VS) and RS size were identified to achieve maximum hydrogen production yield. Published research works on heat-treatment of inoculum introduce many different heat treatment conditions as the optimum heat-treatment condition. Choosing one of these conditions could be somewhat effective on inhibition of methanogens activity but there was no guarantee that the chosen heat treatment is the optimum heat treatment for our inoculum. Therefore, the plan for heat treatment in this study was to choose a range of time and temperature which was widely used in research works and try to find the optimum point for used ASS.

\section{Materials and methods}

\subsection{Raw materials}

Activated sewage sludge (ASS) from inflow of digestion tank in a wastewater treatment plant (Ibaraki-ken, Japan) was used as the inoculum and co-substrate. The sludge was filtered using a $1 \mathrm{~mm}$ screen and stored at $4{ }^{\circ} \mathrm{C}$ until the experiment day. The harvested rice straw (November 2012) was obtained from Tsukuba, Ibaraki-ken, Japan. For this study, rice straw (RS) was cut to 20-30 mm pieces from head to the bottom of the stem together with leaves (to fit the small size of bioreactor), completely mixed and divided to 15 gram portions labelled "Intact RS". Each portion of RS was mixed for 10 seconds using a home mixer. A sieve with mesh number $60(250 \mu \mathrm{m})$ was used to separate powder and very small particles which was not used for this study. The residue was filtered using sieve with mesh number $35(500 \mu \mathrm{m})$; this part was labelled as "Fine RS" $(250-500 \mu \mathrm{m})$. The common industrial name of this lignocellulosic biomass particles size is known as intermediate micronized particles [42]. Using a sieve with mesh number $10(2 \mathrm{~mm})$, particles smaller than $2 \mathrm{~mm}$ and larger than $500 \mu \mathrm{m}$ was separated and labelled as "Medium RS" $(500 \mu \mathrm{m}-2 \mathrm{~mm})$; in industrial scale this size of particles are result of coarse milling process. Residue of sieve with mesh number 10 was labelled "Large RS" whish were (2mm - $20 \mathrm{~mm})$; in industrial plants this is achieved by cutting or crashing of biomass. The prepared samples were kept in disposable plastic cups, sealed using plastic covers and kept in room temperature inside a desiccator prior to usage [24,43].

\subsection{Bioreactor setup}


$150 \mathrm{~mL}$ sealable serum bottles with maximum working levels of $120 \mathrm{~mL}$ were used as batch bioreactors. For each experiment, ASS and RS was prepared according to the design. $\mathrm{pH}$ was set using $\mathrm{HCl} 1$ or/and $0.1 \mathrm{~mol} / \mathrm{L} \mathrm{HCl}$ [44]. According to each experimental design, certain amount of ASS and/or RS was mixed in bioreactors. To provide anaerobic condition, nitrogen gas with injection rate of $5 \mathrm{ml} / \mathrm{sec}$ was injected into each bottle for 2 minutes. Each bottle was air sealed with rubber stoppers and aluminium seals. All of the bottles were checked for probable leakage before being placed in the water bath shaker. Co-digestion was conducted in anaerobic mesophillic condition $\left(35^{\circ} \mathrm{C}\right)$ for 72 hours. The electrical water bath shaker was used to ensure constant temperature and mixing during fermentation process.

\subsection{Inoculum heat treatment optimization}

The first step in this study was to find proper heat treatment time and temperature to treat ASS as a suitable biohydrogen production inoculum. To choose the optimum heat treatment condition of ASS temperature and time of heating were chosen as variables. Range of temperature was $80-100{ }^{\circ} \mathrm{C}$ and time range was chosen at $30-60$ minutes. In this step, 13 tests were conducted with specifications shown in Table 2.

\subsection{Optimization of S/X ratio (based on VS) and initial cultivation pH}

In these experiments, rice straw and heat-treated inoculum was used for bio-hydrogen production optimization. The highest yielding heat treatment from section (2.3) was chosen as the heat treatment method. Using RSM, 13 batch tests were designed considering 2 numerical variables $\mathrm{pH}(4,4.75 \& 5.5)$ and $\mathrm{S} / \mathrm{X}$ ratio $(2: 1,4: 1 \& 6: 1)$. Large rice straw size "large RS" was chosen to be the substrate sample. Variables were coded according to Equation (1) Coded and real values of variables for these experiments are shown in

Table 4 , For each ratio, an exact amount of rice straw was calculated, measured and added to $100 \mathrm{~mL}$ heattreated ASS.

\subsection{Substrate size optimization}

This experiment was carried out to find the optimum size of rice straw for fermentation in mesophillic condition and to find out if size reduction has any effect on bio-hydrogen production. Rice straw with different sizes was used as the substrate and heat-treated ASS as the inoculum. Optimum $\mathrm{pH}$ and optimum S/X ratio achieved in section 2.4 were used to design the experiment. In this stage, triplicate tests were conducted for each size. Total of 12 tests were carried out in bio-reactors as described in section 2.2.

\subsection{Production of bio-hydrogen in optimum condition}

To produce bio-hydrogen from co-digestion of rice straw and activated sewage sludge, triplicate batch tests were carried out. Optimum heat treatment condition, optimum $\mathrm{pH}, \mathrm{S} / \mathrm{X}$ ratio and rice straw size was applied for anaerobic co-digestion of RS and ASS in mesophilic batch bioreactors. By running these experiments the validity of RSM results were verified as well. The experiment procedures and facilities were exactly similar to previous experiments. 


\subsection{Experimental design and data analyses}

RSM, including three levels, two factors and central composite design (CCD) was used in this study to design the experiments, model making, analyses of interactive and individual effects of different factors and finding of optimum conditions. Design Expert version 6.0.6 was used as the RSM software. The variables were coded according to Equation.(1).

$\boldsymbol{x}_{\mathbf{i}}=\frac{\mathbf{X}_{\mathbf{i}}-\mathbf{X}_{\mathbf{i}}^{*}}{\Delta \mathbf{X}_{\mathbf{i}}}$

\section{Equation (1)}

Where $x_{i}$ is the coded value of $\mathrm{i}^{\text {th }}$ test variable, $X_{i}$ is the real value of $\mathrm{i}^{\text {th }}$ test variable, $X_{i}^{*}$ is the value of $\mathrm{Xi}$ at the centre point and $\Delta \mathrm{X}_{\mathrm{i}}$ is the step size.

\subsection{Analytical methods}

Total solid (TS), volatile solid (VS), carbon and nitrogen content $(\mathrm{C}, \mathrm{N})$ were measured according to standard methods [45] for both RS and ASS as well as pH for ASS . Biogas composition including hydrogen, methane, and carbon dioxide, and concentration of each component was determined by a gas chromatograph (GC-8A, SHIMDAZU, Japan). Two detectors were used during measurements. The thermal conductivity detector set on 80 ${ }^{\circ} \mathrm{C}$ and a porapak Q column set on $60{ }^{\circ} \mathrm{C}$. Carrier gas was Nitrogen $\left(\mathrm{N}_{2}\right)$ and head pressure was set to $600 \mathrm{k} \mathrm{Pa}$. All the gas amounts were converted to Normal volume (NTP, $0{ }^{\circ} \mathrm{C}, 1013 \mathrm{hPa}$ ). Based on $\mathrm{GC}$ machine's manual and gas area figures that are the output of the $\mathrm{GC}$ machine, quantity of $\mathrm{H}_{2}, \mathrm{CH}_{4}$ and $\mathrm{CO}_{2}$ in $1 \mathrm{ml}$ of gas samples were calculated using Equation (2), (3) and (4).
$\mathrm{H}_{2}$ area $/ 40,000=\mathrm{qH} 2$
$\mathrm{CH}_{4}$ area $/ 7479.47=\mathrm{qCH} 4$
quantity in $1 \mathrm{~mL}$ gas sample,
Equation (2)
$\mathrm{CO}_{2}$ area $/ 3667.21=\mathrm{qCO} 2$ quantity in $1 \mathrm{~mL}$ gas sample, $\quad$ Equation (3) quantity in $1 \mathrm{~mL}$ gas sample, $\quad$ Equation (4)

In the next step, percentage of each individual gas in total biogas was calculated using Equation (5), (6) and (7).
$\mathrm{H}_{2} \%=100 \mathrm{H}_{2} / \mathrm{q} \mathrm{H}+\mathrm{qCH} 4+\mathrm{qCO}_{2}$
Equation (5)
$\mathrm{CH}_{4} \%=100 \mathrm{CH}_{4} / \mathrm{q} \mathrm{H}_{2}+\mathrm{qCH} 4+\mathrm{qCO}_{2}$
Equation (6)
$\mathrm{CO}_{2} \%=100 \mathrm{CO}_{2} / \mathrm{q} \mathrm{H}_{2}+\mathrm{qCH} 4+\mathrm{qCO}_{2}$
Equation (7)

Using the calculated percentage and the amount of accumulated biogas in the syringe, total quantity of each gas was measured.

\section{Results and discussion}

\subsection{Characterization of raw materials}

Characteristics of activated sewage sludge and rice straw is presented in Table 1 . The data shows that RS has high total solid with an average of $94 \%$ while ASS contains total solid of $0.5 \%$. ASS and RS do not have any significant difference in terms of carbon content percentage in TS. Nitrogen content of ASS is 6.5 times more than RS nitrogen content based on TS. Since nitrogen content of RS is low (less than 1\% of TS) co-digestion of $\mathrm{RS}$ and ASS (high content of nitrogen, $5.86 \%$ of TS) can enhance $\mathrm{C} / \mathrm{N}$ ratio of the mixture. Suitable $\mathrm{C} / \mathrm{N}$ ratio 
range for bio-hydrogen production is always reported to be more than 20 [36,37].Table 1 shows $\mathrm{C} / \mathrm{N}$ ratio of ASS is 5.70 and this low ratio properly shows the necessity of an additional carbon source to increase $\mathrm{C} / \mathrm{N}$ ratio. Rice straw, due to its high content of carbon, could be a reasonable selection as an additional carbon source in codigestion with ASS.

Table 1 - Characteristic of raw materials

\begin{tabular}{lcc}
\hline Parameter & Activated sewage sludge & Rice Straw \\
\hline Total solids & $0.53 \%,(5182 \mathrm{mg} / \mathrm{L})$ & $94 \%$ \\
Volatile solids & $75 \%,(3734 \mathrm{mg} / \mathrm{L})$ & $89 \%$ \\
Carbon content & $33.40 \%$ & $37 \%$ \\
Nitrogen content & $5.86 \%$ & $0.91 \%$ \\
C/N ratio & 5.70 & 40.65 \\
pH & 6.2 & ND \\
\hline
\end{tabular}

N.D. - not determined.

The percentages were calculated on the basis of total solids.

\subsection{Effect of heat treatment optimization of activated sewage sludge}

To find the optimum heat treatment condition, 13 experiments were carried out according to the described details in (Sectin2.3). Coded and actual values of variables as well as actual values of bio-hydrogen production yield (HPY) and percentage, for each experiment indicates in Table 2.

Table 2 - CCD for inoculum heat treatment optimization

\begin{tabular}{|c|c|c|c|c|c|c|}
\hline \multirow{2}{*}{$\begin{array}{c}\text { Experiment } \\
\text { Number }\end{array}$} & \multicolumn{2}{|c|}{ Coded value } & \multicolumn{2}{|c|}{ Real values } & \multirow{2}{*}{$\begin{array}{c}\text { HPY, (NmL } \\
\left.\mathrm{H}_{2} / \mathrm{gVS}\right)\end{array}$} & \multirow{2}{*}{$\begin{array}{c}\mathrm{H}_{2} \% \text { in total } \\
\text { produced biogas }\end{array}$} \\
\hline & $x_{1}$ & $x_{2}$ & $X_{1}$ & $\mathrm{X}_{2}$ & & \\
\hline$\overline{1}$ & -1.41 & 0 & 75.86 & 45.00 & 11.60 & 64.00 \\
\hline 2 & 0 & 0 & 90.00 & 45.00 & 12.00 & 61.08 \\
\hline 3 & 1.41 & 0 & 104.14 & 45.00 & 13.90 & 68.58 \\
\hline 4 & 1 & 1 & 100.00 & 60.00 & 14.67 & 70.00 \\
\hline 5 & -1 & 1 & 80.00 & 60.00 & 13.00 & 68.00 \\
\hline 6 & 0 & 0 & 90.00 & 45.00 & 12.15 & 68.97 \\
\hline 7 & 0 & 1.41 & 90.00 & 66.22 & 13.11 & 68.55 \\
\hline 8 & 0 & 0 & 90.00 & 45.00 & 11.69 & 65.48 \\
\hline 9 & 0 & 0 & 90.00 & 45.00 & 11.50 & 65.88 \\
\hline 10 & 0 & 0 & 90.00 & 45.00 & 11.88 & 62.75 \\
\hline 11 & 0 & -1.41 & 90.00 & 23.79 & 9.20 & 61.23 \\
\hline 12 & 1 & -1 & 100.00 & 30.00 & 11.82 & 66.50 \\
\hline 13 & -1 & -1 & 80.00 & 30.00 & 8.61 & 54.74 \\
\hline
\end{tabular}

$\mathrm{X}_{1:}$ Temperature, ${ }^{\circ} \mathrm{C}$,

$\mathrm{X}_{2}$ : Time, $\min$

$\boldsymbol{e}-\mathbf{3} \boldsymbol{X 1 2}-1.45444 \boldsymbol{e}-\mathbf{3 X 2 2} 2.56833 \boldsymbol{e}-\mathbf{3 X} 1 \mathrm{X} 2$

Equation (8) is the mathematical equation of regression model in the terms of actual factors. This equation is based on the table of analyses of model variance (Table 3 ). 


$$
\begin{array}{r}
\mathbf{H P Y}=+22.63210-0.62878 \mathrm{X}_{1}+0.46847 \mathrm{X}_{2}+4.70000 \boldsymbol{e}^{-3} \boldsymbol{X}_{1}^{2}-1.45444 \boldsymbol{e}^{-3} \boldsymbol{X}_{2}^{2} 2.56833 \boldsymbol{e}^{-3} \mathrm{X}_{1} \mathrm{X}_{2} \\
\text { Equation (8) }
\end{array}
$$

Where HPY is the bio-hydrogen production yield which was dependent on two variables of temperature $\left(\mathrm{X}_{1}\right)$ and time $\left(\mathrm{X}_{2}\right)$.

As it is shown in Table 3, the calculated F-Value (46.15) of the quadratic model is higher than the tabulated Fvalue (2.91) at the level of 5\% and (4.64) at the level of $1 \%$ and it shows that our model predicts the experimental data correctly. Moreover, P-Values for model terms are less than 0.0001 , which is lower than 0.0500 and indicates that the model terms are significant. In our quadratic model the value of coefficient of variation $(\mathrm{CV})$ was $3.11 \%$ which indicates the closeness of the predicted value by our model to the actual values. For an accurate model, "Lack of Fit F-value" should be insignificant. P-value for Lack of Fit > 0.05 is insignificant and indicates the adequacy of the model. "Lack of Fit F-value" of 3.61 implies that the lack of fit is insignificant relative to pure error. "Pred R-Squared" of 0.8347 is in reasonable agreement with the "Adj R-Squared" of 0.9495. "Adeq Precision" measures the signal to noise ratio. Our ratio of 20.958 is greater than 4 that indicate an adequate signal. All these parameters show that this model can be used to navigate the design space.

Table 3 - ANOVA Analysis of heat treatment optimization

\begin{tabular}{lccccc}
\hline \multicolumn{1}{c}{ Source } & $\begin{array}{c}\text { Sum of } \\
\text { Squares }\end{array}$ & $\begin{array}{c}\text { Degree of } \\
\text { freedom }\end{array}$ & $\begin{array}{c}\text { Mean } \\
\text { squares }\end{array}$ & F-value & P-value \\
\hline Model & 31.85 & 5 & 6.37 & 46.15 & $<0.0001$ \\
\multicolumn{1}{c}{ Temp } & 8.27 & 1 & 8.27 & 59.89 & 0.0001 \\
Time & 20.38 & 1 & 20.38 & 147.69 & $<0.0001$ \\
Residual & 0.97 & 7 & 0.14 & & \\
Lack of Fit & 0.71 & 3 & 0.24 & 3.61 & 0.1233 \\
Pure Error & 0.26 & 4 & 0.065 & & \\
Total & 32.81 & 12 & & & \\
C.V & & $3.11 \%$ & & & \\
R-Squared & 0.9706 & & & \\
Adj R-Squared & 0.9495 & & & & \\
Adeq Precision & 20.958 & & & & \\
Pred R-Squared & 0.8347 & & & & \\
\end{tabular}

To generate three-dimensional response surface plots, one variable was kept at its central level and the other one was varied within the experimental range. In Figure 1 bio-hydrogen yield over two numerical variables of time and temperature is estimated by three- dimensional response surface (a) and two-dimensional counter lines (b). 


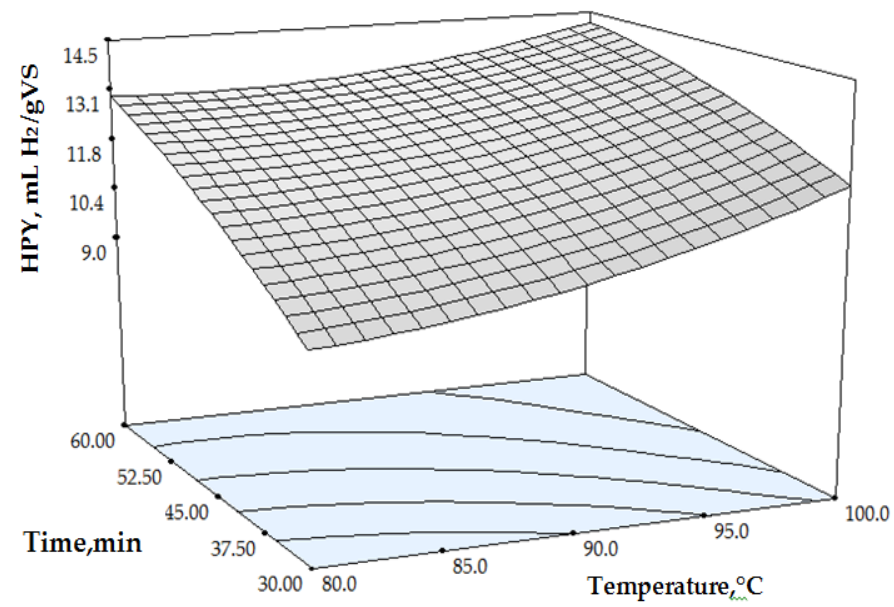

(a)

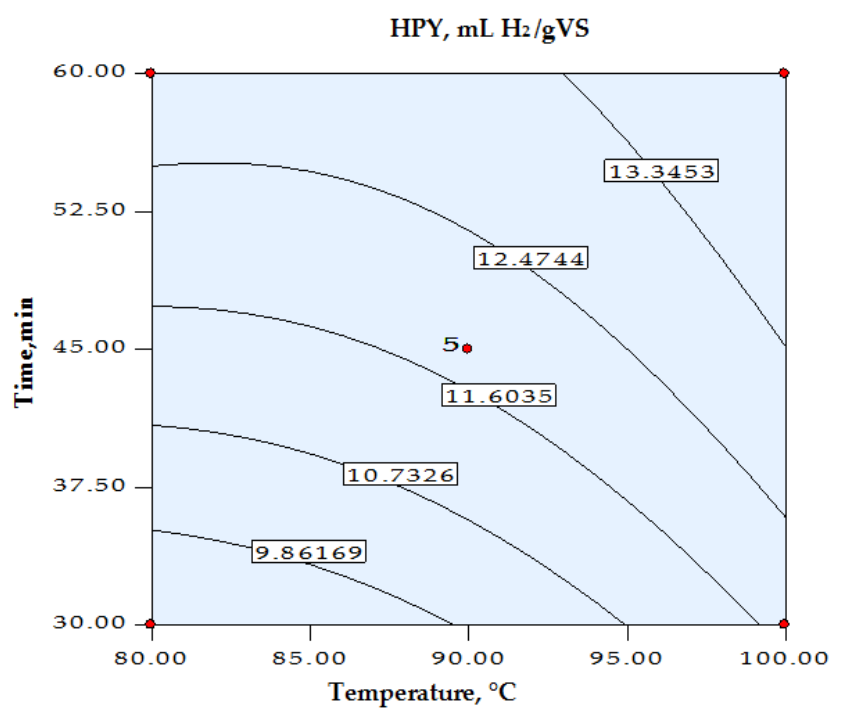

(b)

Figure 1. Effects of time and temperature of heat treatment on HPY a) Response surface plot, b) Counter lines.

Figure 1. shows that bio-hydrogen production yield (HPY) increases with increase of time and temperature. This figure also indicates that variation of time has more significant effect on HPY than variation of temperature.

Figure 2 shows the column chart of actual values of bio-hydrogen production yield. This figure shows a clear comparison of different heat treatment yields as well as comparison of heat-treated ASS with the result of control test. 


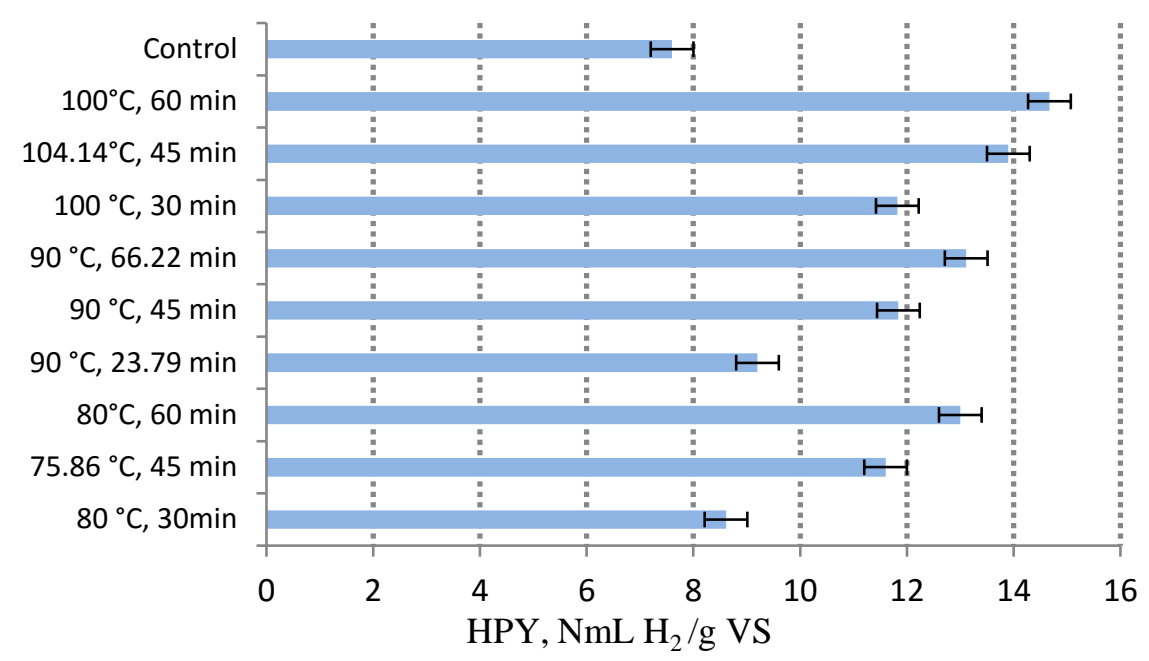

Figure 2 - Actual values for HPY in different heat treatment conditions.

Figure 2, shows that dependency of HPY on time, in a lower temperature was more than dependency of HPY on time in a higher temperature. For instance, in $80{ }^{\circ} \mathrm{C}$ for one minute increase of heat treatment time, HPY increased $0.146 \mathrm{Nml} \mathrm{H}_{2} / \mathrm{gVS}$. In $90{ }^{\circ} \mathrm{C}$ and $100{ }^{\circ} \mathrm{C}$ the increase rates were 0.130 and $0.095 \mathrm{Nml} \mathrm{H}_{2} / \mathrm{gVS}$ respectively. These statements show the important effect of heat treatment time on HPY especially in lower treatment temperatures. Time and temperature of heat treatment were two variables of these experiments and other parameters $(\mathrm{S} / \mathrm{X}$ ratio and $\mathrm{pH})$ were constant. Therefore in control tests untreated ASS was used at the same $\mathrm{pH}$ as of other bioreactors (5.5) and 2 grams of "Large RS" were added to it. HPY was $7.6 \pm 0.50 \mathrm{NmLH}_{2} / \mathrm{gVS}$ being $33 \%$ of total produced biogas at the end of the third day. Comparison of HPY of untreated ASS and HPY of optimum heat treatment condition showed a significant difference between HPY of treated and untreated ASS. Decrease in concentration of bio-hydrogen and increase in concentration of methane in control test compared to HPY of optimum condition clearly showed the activity of methanogens. These results indicated that in untreated ASS, the produced bio-hydrogen was consumed by methanogens.

Triplicate control tests were conducted using heat-treated ASS, no added RS and at the natural pH of ASS (pH: 6.2). Control tests, resulted in average bio-hydrogen production of $1.78 \mathrm{NmL} \mathrm{H}_{2} / \mathrm{gVS}$. Same control tests were repeated for untreated ASS resulted in $2.01 \mathrm{Nml} \mathrm{CH} 4 / \mathrm{g} \mathrm{VS}$ and only $0.07 \mathrm{NmL} \mathrm{H}_{2} / \mathrm{gVS}$.

Data analyses using RSM introduced maximum HPY, maximum concentration of bio-hydrogen gas and minimum production of $\mathrm{CH}_{4}$, at $100^{\circ} \mathrm{C}$ and $60 \mathrm{~min}$. Predicted $\mathrm{HPY}$ in the optimum condition was $14.22 \mathrm{NmL}$ $\mathrm{H}_{2} / \mathrm{g}$ VS and predicted bio-hydrogen concentration was $70.98 \%$ in total biogas. Predicted Methane yield was 0.02 $\mathrm{Nml} \mathrm{CH}_{4} / \mathrm{g}$ VS and predicted methane concentration was $0.074 \%$. The triplicate batch tests were conducted to verify the optimum condition introduced by RSM. These tests resulted in average HPY of $14.10 \pm 0.2 \mathrm{NmL}$ $\mathrm{H}_{2} / \mathrm{gVS}$ at concentration of $69.45 \pm 0.96 \%$ and bio-methane yield in these tests had an average of $0.073 \pm 0.032$ $\mathrm{NmLCH}_{4} / \mathrm{g}$ VS at $0.17 \pm 0.06 \%$ concentration in total produced biogas. This very low production of methane demonstrates clearly that the optimum heat treatment inhibits methanogens activity.

Comparison of the results with other studies shows that $69.45 \%$ is a comparatively high percentage of produced bio-hydrogen in total produced biogas. For instance, Chu et al.,(2013),[31] produced biohydrogen in batch mode, mesophilic condition using heat-treated $\left(100{ }^{\circ} \mathrm{C}, 60 \mathrm{~min}\right)$ mixed culture. They achieved $56 \%$ bio-hydrogen in total produced biogas. Although Mohd Yasin et al., (2011), [33] had done the experiments in thermophilic condition, the highest yield after heat treatment $\left(80{ }^{\circ} \mathrm{C}, 30 \mathrm{~min}\right)$ was $54.4 \%$ bio-hydrogen in total produced biogas. Baghchesaraee et al.,(2008),[14] who investigated effect of different heat treatment temperatures on biohydrogen production from mixed microflora, reported 56.2\% bio-hydrogen production after optimum heat shock 
$\left(65^{\circ} \mathrm{C}, 30 \mathrm{~min}\right)$. All of the mentioned studies show lower percentage of bio-hydrogen in total biogas compared to this study.

Kim et al., (2012), [4] compared treated and untreated digested sewage sludge in a study and reported a higher yield of bio-hydrogen production for the untreated sludge. In thermophilic condition $\left(55^{\circ} \mathrm{C}\right)$ for ten days, they produced $58 \%$ bio-hydrogen in total biogas and the maximum hydrogen yield was $16.58 \mathrm{Nml} \mathrm{H}_{2} / \mathrm{g}$ VS added straw.

None of these studies reported the quantity or percentage of methane or carbon dioxide. Nevertheless, the lower percentage of bio-hydrogen production in those studies compared to this study proved the effectiveness of our heat treatment optimization process.

\subsection{Effect of $\mathrm{S} / \mathrm{X}$ ratio and initial cultivation $\mathrm{pH}$ optimization}

To investigate the effects of VS and initial $\mathrm{pH}$ on HPY, 13 batch tests were designed using RSM. Results of experimental procedures based on real and coded values of two variables ( $\mathrm{S} / \mathrm{X}$ ratio, $\mathrm{pH}$ ) are presented in (table 4).

Table 4 - CCD and results for VS and pH optimization.

\begin{tabular}{|c|c|c|c|c|c|c|c|c|c|}
\hline \multirow[t]{2}{*}{$\begin{array}{c}\text { Experiment } \\
\text { Number }\end{array}$} & \multicolumn{2}{|c|}{$\begin{array}{l}\text { Coded } \\
\text { values }\end{array}$} & \multicolumn{2}{|c|}{ Real values } & \multirow{2}{*}{$\begin{array}{c}\text { HPY } \\
\left(\mathrm{NmL} \mathrm{H}_{2} / \mathrm{g} \mathrm{VS}\right) \\
\text { Actual Value }\end{array}$} & \multirow{2}{*}{$\begin{array}{c}\begin{array}{c}\mathrm{H}_{2} \% \text { in total } \\
\text { produced biogas }\end{array} \\
\text { Actual Value }\end{array}$} & \multirow{2}{*}{$\begin{array}{c}\text { Final } \\
\text { pH }\end{array}$} & \multirow{2}{*}{$\begin{array}{l}\text { Total solid } \\
\text { in each } \\
\text { bioreactor } \\
(\mathbf{m g})\end{array}$} & \multirow[t]{2}{*}{$\begin{array}{c}\text { Substrate } \\
\text { concentration } \\
\text { g VS/L }\end{array}$} \\
\hline & $x_{1}$ & $x_{2}$ & $\mathbf{X}_{1}$ & $X_{2}$ & & & & & \\
\hline 1 & 0 & 0 & 4.00 & 4.75 & 14.96 & 70.00 & 4.02 & 1681.4 & 14.92 \\
\hline 2 & 1 & -1 & 6.00 & 4.00 & 10.59 & 62.60 & 3.90 & 2520.4 & 22.39 \\
\hline 3 & -1 & 1 & 2.00 & 5.50 & 9.40 & 60.70 & 5.30 & 843.5 & 7.46 \\
\hline 4 & 0 & 0 & 4.00 & 4.75 & 13.73 & 69.63 & 4.00 & 1681.4 & 14.92 \\
\hline 5 & 1.41 & 0 & 6.83 & 4.75 & 10.00 & 66.40 & 4.10 & 2868.4 & 25.48 \\
\hline 6 & 0 & 1.41 & 4.00 & 5.81 & 13.40 & 67.20 & 4.06 & 1681.4 & 14.92 \\
\hline 7 & 0 & 0 & 4.00 & 4.75 & 14.69 & 68.30 & 3.92 & 1681.4 & 14.92 \\
\hline 8 & -1 & -1 & 2.00 & 4.00 & 7.20 & 57.00 & 3.90 & 843.5 & 7.46 \\
\hline 9 & 1 & 1 & 6.00 & 5.50 & 12.05 & 64.65 & 4.16 & 2520.4 & 22.39 \\
\hline 10 & -1.41 & 0 & 1.17 & 4.75 & 6.20 & 50.30 & 4.60 & 494.7 & 4.37 \\
\hline 11 & 0 & -1.41 & 4.00 & 3.69 & 12.47 & 60.08 & 3.40 & 1681.4 & 14.92 \\
\hline 12 & 0 & 0 & 4.00 & 4.75 & 14.21 & 68.71 & 4.06 & 1681.4 & 14.92 \\
\hline 13 & 0 & 0 & 4.00 & 4.75 & 14.80 & 67.94 & 3.86 & 1681.4 & 14.92 \\
\hline
\end{tabular}

$\mathrm{X}_{1}$ : VS RS/VS ASS, $\mathrm{X}_{2}: \mathrm{pH}$.

$\mathrm{HPY}=-46.16653+8.02986 \mathrm{X} 1+17.34191 \mathrm{X} 2-0.84164 X_{1}^{2}-1.68633 X_{2}^{2}-0.12283 \mathrm{X} 1 \mathrm{X} 2$

Equation (9) describes the quadratic regression model in the terms of actual factors based on analyses of variance of the model (ANOVA,

Table 5).

HPY $=-46.16653+8.02986 X_{1}+17.34191 X_{2}-0.84164 X_{1}^{2}-1.68633 X_{2}^{2}-0.12283 X_{1} X_{2}$

Equation (9)

Where $\mathrm{X}_{1}$ is the $\mathrm{S} / \mathrm{X}$ ratio (based on VS) and $\mathrm{X}_{2}$ is $\mathrm{pH}$. 
Table 5, indicates our computed F-Value (50.93) for regression model is significantly higher than tabulated Fvalue (2.91) at the level of 5\% and 4.64 at the level of 1\%. ANOVA table also indicates "p-value" of regression model to be less than 0.0001 , which was significantly lower than 0.0500 . Therefore, our model was proven to be a proper model. The "Lack of Fit F-value" was 2.31 and P-value for Lack of Fit was in the insignificant range (0.05-0.99). Therefore the lack of fit was insignificant relative to the pure error and it showed that the model describes the experiment accurately.

The value of coefficient of variation was $5.31 \%$. This low CV indicated the closeness of the predicted value by our model to the actual values. The "Pred R-Squared" of 0.8640 was in reasonable agreement with the "Adj RSquared" of 0.9541. "Adeq Precision" measures the signal to noise ratio. A ratio greater than 4 is desirable. Our ratio of 20.534 indicated an adequate signal. These facts show that this model can be used to navigate the design space.

Table 5 - ANOVA for response surface quadratic Model

\begin{tabular}{|c|c|c|c|c|c|}
\hline Source & $\begin{array}{c}\text { Sum of } \\
\text { Squares }\end{array}$ & $\begin{array}{l}\text { Degree of } \\
\text { freedom }\end{array}$ & $\begin{array}{c}\text { Mean } \\
\text { squares }\end{array}$ & F-value & P-value \\
\hline Model & 100.20 & 5 & 20.04 & 50.93 & $<0.0001$ \\
\hline $\mathbf{X}_{1}$ & 16.28 & 1 & 16.28 & 41.37 & 0.0004 \\
\hline $\mathbf{X}_{2}$ & 3.10 & 1 & 3.10 & 7.89 & 0.0262 \\
\hline Residual & 2.75 & 7 & 0.39 & & \\
\hline Lack of Fit & 1.75 & 3 & 0.58 & 2.31 & 0.2176 \\
\hline Pure Error & 1.01 & 4 & 0.25 & & \\
\hline Total & 102.95 & 12 & & & \\
\hline C.V & $5.31 \%$ & & & & \\
\hline R-Squared & 0.9732 & & & & \\
\hline Adj R-Squared & 0.9541 & & & & \\
\hline Adeq Precision & 20.534 & & & & \\
\hline Pred R-Squared & 0.8640 & & & & \\
\hline
\end{tabular}

In Figure 3, HPY over two numerical variables of $\mathrm{S} / \mathrm{X}$ ratio and $\mathrm{pH}$ was estimated by the three-dimensional response surface (Fig 3,a) and two-dimensional counters lines(Fig 3,b). Figure 3 shows increase of HPY with increase in S/X ratio or $\mathrm{pH}$. This incremental pattern continues until HPY arrives at its peak point. After peak point, the graph shows decrease of HPY with a further increase in S/X ratio and $\mathrm{pH}$. Predicted HPY (by RSM) in peak point ( $\mathrm{pH}=5.01, \mathrm{~S} / \mathrm{X}=4.54: 1$ ) was $14.70 \mathrm{~mL} \mathrm{H}_{2} / \mathrm{g} \mathrm{VS}$, with $69.96 \%$ of total produced biogas. Initial $\mathrm{C} / \mathrm{N}$ ratio in this peak point was calculated to be 29.75.The figure also indicates that variation of $\mathrm{pH}$ in the study range has less effect on HPY compared to the variation of S/X ratio. 

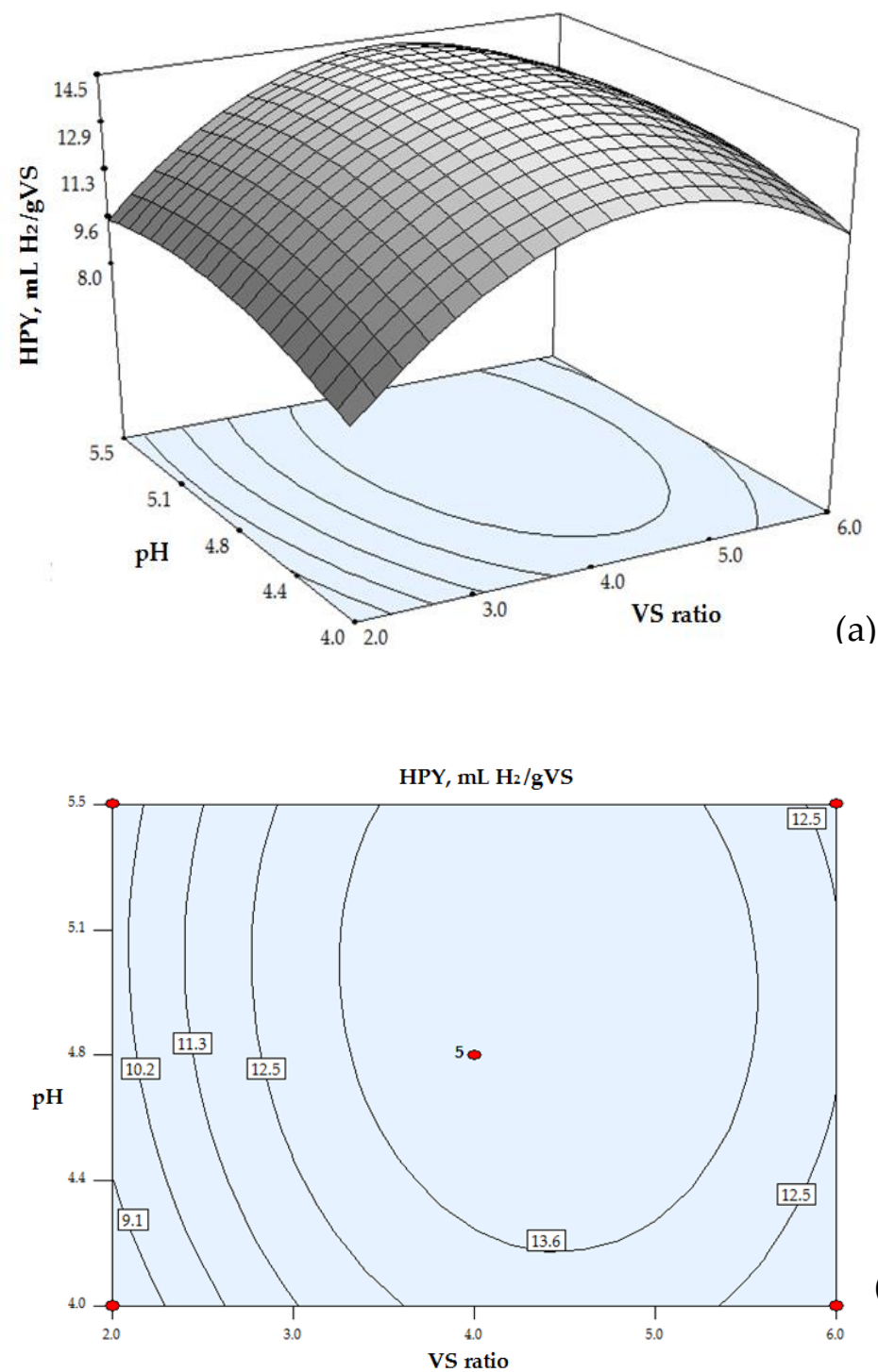

(b)

Figure 3. Effects of $\mathrm{S} / \mathrm{X}$ ratio and $\mathrm{pH}$ on HPY. a) Response surface plot, b) Two-dimensional contour lines.

Triplicate control tests were conducted using heat-treated ASS, no added RS and at the natural pH of ASS (pH: 6.2). These control tests were designed to show the importance and effectiveness of VS ratio optimization, and changing of $\mathrm{pH}$ to the optimum value. Control tests, resulted in average bio-hydrogen production of $1.78 \mathrm{NmL}$ $\mathrm{H}_{2} / \mathrm{g}$ VS. This very low HPY contribution from the inoculum clearly showed that conducting co-digestion using ASS and RS has been a successful approach. It also showed that natural $\mathrm{pH}$ of ASS is not suitable for biohydrogen production and changing $\mathrm{pH}$ of ASS to a more acidic condition enhanced bio-hydrogen production. also we can deduce that $12.92 \mathrm{NmL} \mathrm{H}_{2} / \mathrm{g}$ VS is produced by degradation of RS itself in optimum condition.

Pakarinen et al.,(2008), [41] investigated the effect of VS ratio $(1: 1,1.5: 1$ and 2:1) and pH (4, 5 \& 6) using heattreated mixed culture. The highest bio-hydrogen yield of $4.0 \mathrm{mLH}_{2} / \mathrm{g}$ VS in ratio $2: 1$, pH 5 and mesophilic condition was achieved. In this study, we chose to investigate VS ratio higher than 2 to cover the gap in Pakarinen et al.'s study.

Several studies which were conducted in mesophilic condition using raw lignocellulosic waste materials show lower yield compared to our study. For instance, Nasirian et al., (2011), [13] used raw wheat straw as substrate 
and heat-treated $\left(70^{\circ}\right.$ for $\left.60 \mathrm{~min}\right)$ mixed culture as inoculum in mesophilic condition in the control tests of their study; the yield of bio-hydrogen production was $6.4 \mathrm{NmL} \mathrm{H}_{2} / \mathrm{g}$ VS. Fan et al.,(2004), [35] produced $1 \mathrm{NmL} \mathrm{H}_{2} / \mathrm{g}$ VS from raw wheat straw using infrared treated cow dung compost as inoculum in mesophilic condition. Li and Chen., (2007), [46] produced $9 \mathrm{NmL} \mathrm{H}_{2} / \mathrm{g}$ VS from raw corn straw using pure culture as inoculum in mesophilic condition.

This high yield of bio-hydrogen production in mesophilic condition from raw rice straw proves the significant effect of optimization of different factors on bio-hydrogen production yield.

Data gathered in previous studies on initial concentrations of substrates and/or inoculums or $\mathrm{C} / \mathrm{N}$ ratio introduces various conditions to be optimal. It can be deduced from versatility of these results that optimum initial concentration is highly dependent on the substrate and the inoculum characteristics. Hence it should be logical to measure initial concentration of the substrate and inoculum for each individual study rather than referring to the previous works done with different substrates and inoculums.

\subsection{Effect of rice straw size on bio-hydrogen production}

The experiment details are described in section 2.5, and the results of triplicate tests for each rice straw size are presented in Figure 4. The results indicate, "Large RS" has the highest yield of bio-hydrogen production among the other rice straw sizes with the value of $14.46 \pm 0.47 \mathrm{Nml} \mathrm{H}_{2} / \mathrm{g}$ VS. These results show that size reduction does not always have a positive effect on bio-hydrogen production yield. As it is obvious, the yield of "Large RS" is almost 2.5 times more than "Fine RS".

Many studies are done using fine particle size of lignocellulosic waste materials for biogas production supported with the theory that size reduction will increase the available specific area for activity of microorganism and ruin the crystallinity of lignocellulosic material and make biomass more bio-degradable for biogas production [42]. Results of this study contradict this theory. Several studies are done on effect of size reduction on biodegradability of lignocellulosic biomass and proven that size reduction effectively increases biodegradability of biomass [42,47] .but it does not mean that size reduction increase biogas production as well. As our study indicates, size reduction in excessive levels is not always a proper solution to increase bio-hydrogen production yield. Izumi et al.,(2010),[48] reported that "Excessive size reduction of the substrate caused VFA accumulation, resulting in decreased biogas production and decreased solubility in the anaerobic digestion process". In a successful biohydrogen production highest yield will achieved when acetic acid is the final product, and lower yield of bio-hydrogen will achieved when butyric acid is the final product [1].. Izumi et al.,( 2010),[48] reported that for smaller particle size production of butyric acid increases sharply and production of acetic acid decreases sharply. Motte et al., (2013), also reported that a decrease of particle size has negative effect on the biogas production. From these studies it can be deduced that smaller RS particles enforce fermentation process to production of butyric acid and hydrogen:

$\underline{\mathrm{C}}_{6} \underline{\mathrm{H}}_{12} \underline{\mathrm{O}}_{6} \rightarrow \mathrm{CH}_{3} \underline{\mathrm{CH}}_{2} \mathrm{CH}_{2} \mathrm{COOH}+2 \mathrm{H}_{2}+2 \mathrm{CO}_{2} \quad$ Equation (10) [1]

While larger RS particles shift the fermentation process to acetic acid and hydrogen production:

$\mathrm{C}_{6} \mathrm{H}_{12} \mathrm{O}_{6}+2 \mathrm{H}_{2} \mathrm{O} \rightarrow 2 \mathrm{CH}_{3} \mathrm{COOH}+4 \mathrm{H} 2+2 \mathrm{CO} 2 \quad$ Equation (11) [1]

It can be clearly understood from these equation that biohydrogen production is theatrically 2times more in Equation (11) compared to Equation (10).

On the other hand, there is a theory in design of fixed bed (packed bed) bioreactors which says using fixed bed bioreactors will increase and enhance the connectivity between two phases of materials in the fermentation environment. There is the possibility that in this study the large particles of rice straw "Large RS" were acting similar to packing materials in fixed bed bioreactors and therefore, giving more possibility to the microorganism to immobilize on RS particles. On the other hand, mixing was properly done during the fermentation process using a shaker water batch, therefore the low HPY of "Fine RS" could not be due to the settling down of RS particles in the bioreactors. 
On the other hand Lignocellulosic materials have an internal and an external surface area. Increase in both of these surfaces, improves digestibility of the materials when exposed to enzymes. External surface area size depends on shape and size whereas the internal surface size relates to capillarity structure of the cellulose fibers the size of the penetrating reactant [49].Although size reduction increases external surface of cellulose fibers; it does not impact their internal surface area size. Exposure to humidity on the other hand, causes swelling of the fibers and significantly increases internal surface area size which in turns has a positive effect on digestibility of the material. In case of very highly milled small particles, absorption of humidity causes re-formation of cellulose crystals and decrease in digestibility of lignocelluloses [50][51].

It can be understood from figure 4 , that for particle sizes smaller than $2 \mathrm{~mm}$, negative effect of re-crystallization is more than the positive effect of increased surface area size. This leads to a reduction in digestibility of lignocellulose and consequently decreases of HPY.

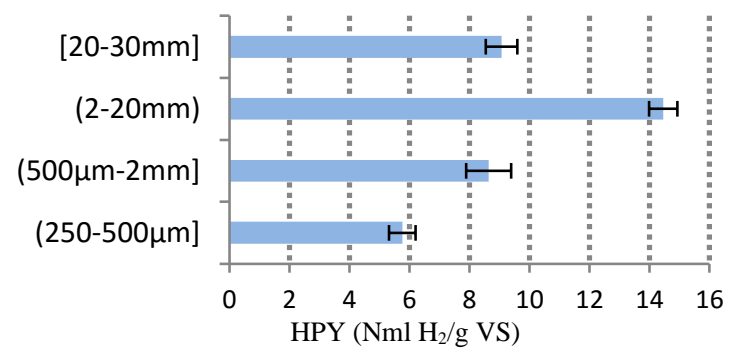

Figure 4 - HPY for different RS sizes.

\subsection{Optimum bio-hydrogen production}

Triplicate test were carried out to produce bio-hydrogen from co-digestion of rice straw and activated sewage sludge in optimum conditions. Optimum heat treatment condition of ASS $\left(100^{\circ} \mathrm{C}, 60 \mathrm{~min}\right)$, optimum $\mathrm{pH}(5.01)$, VS ratio (4.54:1) and RS size (Large RS) were chosen to conduct the experiments. These experiments resulted in average bio-hydrogen production of $14.54 \pm 0.29 \mathrm{NmL} \mathrm{H}_{2} / \mathrm{g}$ VS. Concentration of bio-hydrogen in total biogas was $69.95 \pm 0.82 \%$. Methane production yield was $0.081 \pm 0.005 \mathrm{NmL} / \mathrm{g}$ VS which was $0.12 \pm 0.03 \%$ of total produced biogas. This low production of methane shows a proper inhibition of methanogens activity which is one of the reasons of high HPY. Due to the inhibition of methanogens, nutrition, carbon and nitrogen were more accessible for hydrogen producing bacteria. Also very low amounts of hydrogen gas were consumed by methanogens bacteria in methane production process. On the other hand "Large RS" particles (2-20 mm) which were used in these experiments had more specific surface area and less crystallinity of cellulose fibers compare to "Intact RS" particles [20-30mm] [23]. The RS particles smaller than $2 \mathrm{~mm}$ had more specific surface area and less crystallinity of cellulose in dry environment compare to larger particles. Exposure to humidity will increase crystallinity and therefore decrease digestibility of cellulose in these particles [49-51]. Therefore proper size of RS particles had a bold role in high HPY. Table 6 shows the final result of this study and several other studies. This table shows that all other studies conducted in mesophilic condition had lower yield of bio-hydrogen production compare to this study.

All of the reported studies in table 6 , were conducted in batch mode and reported $\mathrm{H}_{2}$ yield is in std condition $(0$ ${ }^{\circ} \mathrm{C}, 1013 \mathrm{hPa}$ ). Used substrates are raw and only size reduction in different levels is applied. Reported heat treatments in table 6, have either low temperature or short treatment time except for Fan et al. (2006) [52]. This low temperature and short time had the lowest HPY in our heat treatment optimization process. This comparison again shows the effectiveness of all optimization processes done in this study. 
Table 6 - Comparison with other studies

\begin{tabular}{|c|c|c|c|c|c|}
\hline Culture & Inoculum treatment condition & Substrate & $\begin{array}{c}\mathbf{T} \\
\left({ }^{\circ} \mathbf{C}\right)\end{array}$ & $\begin{array}{c}\mathrm{H}_{2} \text { yield } \\
(\mathrm{Nml} \\
\left.\mathrm{H}_{2} / \mathrm{gVS}\right)\end{array}$ & References \\
\hline Cow dung compost & Infrared oven for $120 \mathrm{~min}$ & Wheat straw & 36 & 1 & [52] \\
\hline Clostridium butyricum & None & Corn straw & 35 & 9 & [46] \\
\hline Cow dung compost & Aeration for $3 \mathrm{~h}$ in $50^{\circ} \mathbf{C}$ & Corn straw & 36 & 3.16 & [53] \\
\hline $\begin{array}{l}\text { Digested sewage } \\
\text { sludge }\end{array}$ & Boiling for $30 \mathrm{~min}$ & Grass silage & 35 & 11.5 & [41] \\
\hline Digested cow manure & Boiling for $30 \mathrm{~min}$ & Grass silage & 35 & 0.3 & [41] \\
\hline $\begin{array}{l}\text { Mix culture CSTR } \mathrm{H}_{2} \\
\text { sludge }\end{array}$ & $70^{\circ} \mathrm{C}$ for $60 \mathrm{~min}$ & Wheat straw & 36 & 6.4 & [13] \\
\hline $\begin{array}{l}\text { Digested Sewage } \\
\text { sludge }\end{array}$ & None & Rice straw & 55 & 16.57 & [4] \\
\hline $\begin{array}{l}\text { Activated sewage } \\
\text { sludge }\end{array}$ & $100^{\circ} \mathrm{C}$ for $60 \mathrm{~min}$ & Rice straw & 35 & $14.54 \pm 0.29$ & This study \\
\hline
\end{tabular}

Kim et al., (2012),[4] is one of the works emphasized on untreated mixed culture. Although in their study energy was saved by using untreated sludge, they lost more energy by conducting the experiment for ten days in thermophilic condition $\left(55^{\circ} \mathrm{C}\right.$ ). Size reduction of RS (smaller than $2 \mathrm{~mm}$ ) to very small particles was another energy consuming process which was done by Kim et al,. (2012), [4]. Furthermore, the achieved yield was only 1.14 times more than result of this study, considering that this study was done in mesophilic condition $\left(35{ }^{\circ} \mathrm{C}\right)$ and used larger size of RS.

\section{Conclusion}

This study proved heat treatment of activated sewage sludge as the inoculum can significantly increase biohydrogen production yield and concentration. Bio-hydrogen yield of heat-treated inoculum was significantly higher than the untreated inoculum. Moreover, optimization of heat treatment condition can enhance biohydrogen production by successful inhibition of methanogens activity. Data analyses of results using response surface methodology (RSM) showed that the most suitable heat-treatment of sewage sludge as inoculum was at $100{ }^{\circ} \mathrm{C}$ for 60 minutes.

This study proved the effectiveness of volatile solids (VS) ratio and $\mathrm{pH}$ optimization on bio-hydrogen production yield. It also demonstrated that optimized VS ratio and $\mathrm{pH}$ can enhance bio-hydrogen production in mesophilic condition and increase concentration of bio-hydrogen in total biogas. Furthermore, adding rice straw to activated sewage sludge as a carbon source had successful results and enhanced VS ratio, C/N ratio and concentration of organic material in bioreactor environment. Analyses of data using RSM introduced optimum condition for biohydrogen production from co-digestion of raw rice straw and activated sewage sludge to be at $\mathrm{pH}=5.01$ and VS ratio $=4.54: 1$.

Results of this study have also shown that rice straw size reduction to powder size (the size which is widely used in lab scale studies) has a negative effect on bio-hydrogen production yield. Highest yield of biohydrogen was 
achieved by using rice straw particles which were not intact but were smaller than $20 \mathrm{~mm}$ and larger than $2 \mathrm{~mm}$ in both length and thickness.

\section{Acknowledgement}

Special thanks to Japan Student Services Organization (JASSO) and graduate school of life and environmental sciences, University of Tsukuba for supporting and providing the laboratory facilities of this research. 
Reference List

[1] F.R. Hawkes, R. Dinsdale, D.L. Hawkes, I. Hussy, Sustainable fermentative hydrogen production: challenges for process optimisation, Int J Hydrogen Energy. 27 (2002) 1339-1347.

[2] K. Zhang, N. Ren, C. Guo, A. Wang, G. Cao, Effects of various pretreatment methods on mixed microflora to enhance biohydrogen production from corn stover hydrolysate, Journal of Environmental Sciences. 23 (2011) 1929-1936.

[3] S.I. Gadow, Y. Li, Y. Liu, Effect of temperature on continuous hydrogen production of cellulose, Int J Hydrogen Energy. 37 (2012) 15465-15472.

[4] M. Kim, Y. Yang, M.S. Morikawa-Sakura, Q. Wang, M.V. Lee, D. Lee, C. Feng, Y. Zhou, Z. Zhang, Hydrogen production by anaerobic co-digestion of rice straw and sewage sludge, Int J Hydrogen Energy. 37 (2012) 3142-3149.

[5] A. Ravindran, S. Adav, S. Yang, Effect of heat pre-treatment temperature on isolation of hydrogen producing functional consortium from soil, Renewable Energy. 35 (2010) 2649-2655.

[6] G.M. Shida, A.R. Barros, C.M.d. Reis, E.L.C.d. Amorim, M.H. Rissato Zamariolli Damianovic, E.L. Silva, Long-term stability of hydrogen and organic acids production in an anaerobic fluidized-bed reactor using heat treated anaerobic sludge inoculum, Int J Hydrogen Energy. 34 (2009) 3679-3688.

[7] K. Jung, D. Kim, H. Kim, H. Shin, Optimization of combined (acid + thermal) pretreatment for fermentative hydrogen production from Laminaria japonica using response surface methodology (RSM), Int J Hydrogen Energy. 36 (2011) 9626-9631.

[8] K. Zhang, N. Ren, A. Wang, Enhanced biohydrogen production from corn stover hydrolyzate by pretreatment of two typical seed sludges, Int J Hydrogen Energy. 39 (2014) 14653-14662.

[9] C. Liu, W. Shi, M. Kim, Y. Yang, Z. Lei, Z. Zhang, Photocatalytic pretreatment for the redox conversion of waste activated sludge to enhance biohydrogen production, Int J Hydrogen Energy. 38 (2013) 7246-7252.

[10] H. Wang, M. Fang, Z. Fang, H. Bu, Effects of sludge pretreatments and organic acids on hydrogen production by anaerobic fermentation, Bioresour. Technol. 101 (2010) 8731-8735.

[11] X. Jia, C. Zhu, M. Li, B. Xi, L. Wang, X. Yang, X. Xia, J. Su, A comparison of treatment techniques to enhance fermentative hydrogen production from piggery anaerobic digested residues, Int J Hydrogen Energy. 38 (2013) 8691-8698.

[12] S. Kim, Biological hydrogen production by anaerobic digestion of food waste and sewage sludge treated using various pretreatment technologies. Biodegradation. 24 (2013) 753-764.

[13] N. Nasirian, M. Almassi, S. Minaei, R. Widmann, Development of a method for biohydrogen production from wheat straw by dark fermentation, Int J Hydrogen Energy. 36 (2011) 411-420.

[14] B. Baghchehsaraee, G. Nakhla, D. Karamanev, A. Margaritis, G. Reid, The effect of heat pretreatment temperature on fermentative hydrogen production using mixed cultures, Int J Hydrogen Energy. 33 (2008) 40644073. 
[15] J. Wang, W. Wan, Comparison of different pretreatment methods for enriching hydrogen-producing bacteria from digested sludge, Int J Hydrogen Energy. 33 (2008) 2934-2941.

[16] F. Kargi, N.S. Eren, S. Ozmihci, Bio-hydrogen production from cheese whey powder (CWP) solution: Comparison of thermophilic and mesophilic dark fermentations, Int J Hydrogen Energy. 37 (2012) 8338-8342.

[17] A. Scoma, L. Bertin, F. Fava, Effect of hydraulic retention time on biohydrogen and volatile fatty acids production during acidogenic digestion of dephenolized olive mill wastewaters, Biomass Bioenergy. 48 (2013) $51-58$.

[18] Y. Lo, Y. Su, C. Cheng, J. Chang, Biohydrogen production from pure and natural lignocellulosic feedstock with chemical pretreatment and bacterial hydrolysis, Int J Hydrogen Energy. 36 (2011) 13955-13963.

[19] Y. Fan, G. Zhang, X. Guo, Y. Xing, M. Fan, Biohydrogen-production from beer lees biomass by cow dung compost, Biomass Bioenergy. 30 (2006) 493-496.

[20] K. Vijayaraghavan, D. Ahmad, M. Khairil Bin Ibrahim, Biohydrogen generation from jackfruit peel using anaerobic contact filter, Int J Hydrogen Energy. 31 (2006) 569-579.

[21] N.H.M. Yasin, T. Mumtaz, M.A. Hassan, N. Abd Rahman, Food waste and food processing waste for biohydrogen production: A review, J. Environ. Manage. 130 (2013) 375-385.

[22] Y. Zheng, J. Zhao, F. Xu, Y. Li, Pretreatment of lignocellulosic biomass for enhanced biogas production, Progress in Energy and Combustion Science. 42 (2014) 35-53.

[23] V.B. Agbor, N. Cicek, R. Sparling, A. Berlin, D.B. Levin, Biomass pretreatment: Fundamentals toward application, Biotechnol. Adv. 29 (2011) 675-685.

[24] A. Barakat, F. Monlau, A. Solhy, H. Carrere, Mechanical dissociation and fragmentation of lignocellulosic biomass: Effect of initial moisture, biochemical and structural proprieties on energy requirement, Appl. Energy. 142 (2015) 240-246.

[25] A. Fangkum, A. Reungsang, Biohydrogen production from sugarcane bagasse hydrolysate by elephant dung: Effects of initial pH and substrate concentration, Int J Hydrogen Energy. 36 (2011) 8687-8696.

[26] M.E. Nissilä, C. Lay, J.A. Puhakka, Dark fermentative hydrogen production from lignocellulosic hydrolyzates - A review, Biomass Bioenergy. 67 (2014) 145-159.

[27] C. Drapacho, N.P. Nhuam, T.H. Walker, Biofuels Engineering Process Technology. Mc Graw Hill, 2008.

[28] R. Kothari, D.P. Singh, V.V. Tyagi, S.K. Tyagi, Fermentative hydrogen production - An alternative clean energy source, Renewable and Sustainable Energy Reviews. 16 (2012) 2337-2346.

[29] C. Ramos, G. Buitrón, I. Moreno-Andrade, R. Chamy, Effect of the initial total solids concentration and initial $\mathrm{pH}$ on the bio-hydrogen production from cafeteria food waste, Int J Hydrogen Energy. 37 (2012) 1328813295.

[30] Y.M. Wong, T.Y. Wu, J.C. Juan, A review of sustainable hydrogen production using seed sludge via dark fermentation, Renewable and Sustainable Energy Reviews. 34 (2014) 471-482. 
[31] C. Chu, L. Tung, C. Lin, Effect of substrate concentration and $\mathrm{pH}$ on biohydrogen production kinetics from food industry wastewater by mixed culture, Int J Hydrogen Energy. 38 (2013) 15849-15855.

[32] D. Infantes, A. González del Campo, J. Villaseñor, F.J. Fernández, Influence of pH, temperature and volatile fatty acids on hydrogen production by acidogenic fermentation, Int J Hydrogen Energy. 36 (2011) 15595-15601.

[33] N.H. Mohd Yasin, N.A. Rahman, H.C. Man, M.Z. Mohd Yusoff, M.A. Hassan, Microbial characterization of hydrogen-producing bacteria in fermented food waste at different $\mathrm{pH}$ values, Int J Hydrogen Energy. 36 (2011) 9571-9580.

[34] G. Davila-Vazquez, F. Alatriste-Mondragón, A. de León-Rodríguez, E. Razo-Flores, Fermentative hydrogen production in batch experiments using lactose, cheese whey and glucose: Influence of initial substrate concentration and pH, Int J Hydrogen Energy. 33 (2008) 4989-4997.

[35] Y. Fan, C. Li, J. Lay, H. Hou, G. Zhang, Optimization of initial substrate and pH levels for germination of sporing hydrogen-producing anaerobes in cow dung compost, Bioresour. Technol. 91 (2004) 189-193.

[36] H. Argun, F. Kargi, I.K. Kapdan, R. Oztekin, Biohydrogen production by dark fermentation of wheat powder solution: Effects of $\mathrm{C} / \mathrm{N}$ and $\mathrm{C} / \mathrm{P}$ ratio on hydrogen yield and formation rate, Int J Hydrogen Energy. 33 (2008) $1813-1819$.

[37] C.Y. Lin, C.H. Lay, Carbon/nitrogen-ratio effect on fermentative hydrogen production by mixed microflora, Int J Hydrogen Energy. 29 (2004) 41-45.

[38] D.D. Androga, E. Özgür, I. Eroglu, U. Gündüz, M. Yücel, Significance of carbon to nitrogen ratio on the long-term stability of continuous photofermentative hydrogen production, Int J Hydrogen Energy. 36 (2011) 15583-15594.

[39] P. Phowan, P. Danvirutai, Hydrogen production from cassava pulp hydrolysate by mixed seed cultures: Effects of initial pH, substrate and biomass concentrations, Biomass Bioenergy. 64 (2014) 1-10.

[40] A. Fangkum, A. Reungsang, Biohydrogen production from sugarcane bagasse hydrolysate by elephant dung: Effects of initial pH and substrate concentration, Int J Hydrogen Energy. 36 (2011) 8687-8696.

[41] O. Pakarinen, A. Lehtomäki, J. Rintala, Batch dark fermentative hydrogen production from grass silage: The effect of inoculum, pH, temperature and VS ratio, Int J Hydrogen Energy. 33 (2008) 594-601.

[42] A. Barakat, C. Mayer-Laigle, A. Solhy, R.A.D. Arancon, H. de Vries, R. Luque, Mechanical pretreatments of lignocellulosic biomass: towards facile and environmentally sound technologies for biofuels production, RSC Adv. 4 (2014) 48109-48127.

[43] G.G.D. Silva, M. Couturier, J. Berrin, A. Buléon, X. Rouau, Effects of grinding processes on enzymatic degradation of wheat straw, Bioresour. Technol. 103 (2012) 192-200.

[44] G. Luo, L. Xie, Z. Zou, Q. Zhou, J. Wang, Fermentative hydrogen production from cassava stillage by mixed anaerobic microflora: Effects of temperature and pH, Appl. Energy. 87 (2010) 3710-3717.

[45]DIN Standard Methods for Examination of Water, Wastewater and Sludge Sludge and Sediments (Group S); Water and Wastewater (Group H, Deutsches institute für Normung e. V, Germany, 1985. 
[46] D. Li, H. Chen, Biological hydrogen production from steam-exploded straw by simultaneous saccharification and fermentation, Int J Hydrogen Energy. 32 (2007) 1742-1748.

[47] J.-. Motte, R. Escudié, J. Hamelin, J.-. Steyer, N. Bernet, J.-. Delgenes, C. Dumas, Substrate milling pretreatment as a key parameter for Solid-State Anaerobic Digestion optimization, Bioresour. Technol. 173 (2014) 185-192.

[48] K. Izumi, Y. Okishio, N. Nagao, C. Niwa, S. Yamamoto, T. Toda, Effects of particle size on anaerobic digestion of food waste, Int. Biodeterior. Biodegrad. 64 (2010) 601-608.

[49] L.P. Walker, D.B. Wilson, Enzymatic hydrolysis of cellulose: An overview, Bioresour. Technol. 36 (1991) 3-14.

[50] M.J. Taherzadeh, K. Karimi, Pretreatment of Lignocellulosic Wastes to Improve Ethanol and Biogas Production: A Review, International journal of molecular science. 9 (2008) 1621-1651.

[51] L.T. Fan, Y. Lee, D.H. Beardmore, Mechanism of the enzymatic hydrolysis of cellulose: Effects of major structural features of cellulose on enzymatic hydrolysis, Biotechnol. Bioeng. 22 (1980) 177-199.

[52] Y. Fan, Y. Zhang, S. Zhang, H. Hou, B. Ren, Efficient conversion of wheat straw wastes into biohydrogen gas by cow dung compost, Bioresour. Technol. 97 (2006) 500-505.

[53] M. Zhang, Y. Fan, Y. Xing, C. Pan, G. Zhang, J. Lay, Enhanced biohydrogen production from cornstalk wastes with acidification pretreatment by mixed anaerobic cultures, Biomass Bioenergy. 31 (2007) 250-254. 